\title{
Cooperative Learning With a Focus on the Social: A Pedagogical Proposal for the EFL Classroom
}

\section{Aprendizaje cooperativo con un enfoque social: una propuesta pedagógica para la clase de inglés*}

\author{
Janeth Juliana Contreras León \\ jcontre7@gmail.com \\ Colegio Bravo Páez IED, Bogotá, Colombia \\ Claudia Marcela Chapetón Castro \\ cchapeton@pedagogica.edu.co \\ Universidad Pedagógica Nacional, Bogotá, Colombia
}

This article is a report of a pedagogical intervention which was developed with a group of seventh graders during their English as a foreign language class in a public school in Bogotá. It is part of an investigation in which the main purpose was to foster students' classroom interaction through the use of cooperative learning principles from a dialogical perspective that focused on social aspects of students' school lives. Thus, the instructional design incorporated a methodology that focused on the students' realities and provided opportunities for dialogue, cooperation, and reflection. From a pedagogical perspective, this experience promoted changes in the classroom practices allowing a new vision of group work, encouraging personal growth and social awareness among participants.

Key words: Classroom as social reality, cooperative learning, English as a foreign language, critical pedagogy.

* Received: November 11, 2015. Accepted: June 24, 2016.

How to cite this article (APA 6th ed.):

Contreras León, J. J., \& Chapetón Castro, C. M. (2016). Cooperative learning with a focus on the social: A pedagogical proposal for the EFL classroom. HOW, 23(2), 125-147. http://dx.doi.org/10.19183/how.23.2.321.

This article is licensed under a Creative Commons Attribution-NonCommercial-NoDerivatives 4.0 International License. License Deed can be consulted at http://creativecommons.org/licenses/by-nc-nd/4.0/. 
Este artículo es un reporte de una intervención pedagógica que se desarrolló con un grupo de estudiantes de séptimo grado durante sus clases de inglés como lengua extranjera, en una escuela pública de Bogotá. Esta experiencia es parte de una investigación en la que el objetivo principal era fomentar la interacción en el aula a través del uso de aprendizaje cooperativo desde una perspectiva dialógica, que se centró en los aspectos sociales de la vida escolar de los participantes. Por lo tanto, el diseño instruccional incorporó una metodología enfocada en la realidad escolar y brindó oportunidades para el diálogo, la cooperación y la reflexión. Desde una perspectiva pedagógica, esta experiencia promovió cambios en las prácticas de aula que permitieron una nueva visión del trabajo en grupo, fomentando el crecimiento personal y la conciencia social entre los participantes.

Palabras clave: aprendizaje cooperativo, aula como realidad social, inglés como lengua extranjera, pedagogía crítica.

\section{Introduction}

According to Vygotsky (1978), Malamah-Thomas (1991), and Tarone (2007), language learning is a social process that is achieved through interaction. The development of interaction creates opportunities to develop communicative skills and to acquire the ability to establish and maintain personal relationships. Unfortunately, at most Colombian public schools, students face a socially deprived setting characterized by different social and economic adversities such as urban violence, low-income and one-parent families, poor housing conditions, and few opportunities for social promotion (Guzmán, 2006; Palacios \& Chapetón, 2014; Parga, 2011; Rojas, 2015). Students' interaction in many English as a foreign language (EFL) classrooms reflect the social context and the realities that students are facing and living, thus engaging in disrespectful behaviors or disturbing attitudes and activities such as disruptive talking, clowning, verbal insults, rudeness, and bullying that hinder the teaching and learning processes. Students, in this type of setting, are found to be displaying a lack of social skills which are evidenced when a person does not have the necessary abilities to get along with others and to create and maintain relationships (Areritola, Breen, \& Paz, 2009).

Consequently, it is necessary to examine alternatives that can help teachers to deal with these problems given that classroom interaction is an essential part of an EFL teaching and learning process and that, at public schools, the students' exposure to the language occurs mainly in the classroom.

This study emerged as an opportunity to foster students' interaction among seventh graders of a public school in Bogotá through the use of cooperative learning principles from a dialogical perspective as an alternative to overcome disrespectful, rude, and disruptive behaviors that are affecting not only our schools but also our society. This study was sustained by a critical pedagogy framework to explore some cooperative learning principles that were implemented during classroom interaction in an EFL setting. 
In this article we focus on the construction, implementation, and achievements of the pedagogical intervention as an experience that can be useful for teachers who are interested in fostering social interaction and cooperative learning in their teaching practice.

\section{Fundamental Concepts}

\section{Critical Pedagogy: An Opportunity for Social Change}

Freire and Shor (1987) define critical pedagogy as an active pedagogy which enables students to become truly participatory members of a community who not only belong to the society but who can create and re-create knowledge and society in and outside the classroom. Freire (2002) proposes a dialogical education, or liberating education, that transcends to an education of questioning. It is based upon dialogue that seeks not only to increase active student participation in the classroom, but also to develop a critical social consciousness among students.

This approach, as Freire (2002) claims, enables the humanization of teachers and students and the transformation of classrooms that encourage students to understand and transform their reality. He conceives education a liberatory process where learners come to consciousness, and a liberating teacher is one who uses questions to develop a dialogue with his/her students. This dialogue allows the development of a critical consciousness. In a dialogic process, students become active agents in their learning process. In that sense, education becomes the means to transform social reality.

It is our belief that the first step to adopt this perspective is to become aware of the world in which students live in order to develop meaningful learning by means of reflection and dialogue. This critical perspective constitutes the central part of this pedagogical intervention that aims to value students' voices, beliefs, attitudes, knowledge, and experiences, and seeks the development of students' critical consciousness as well as their social skills through the implementation of cooperative learning.

\section{Cooperative Learning: A Social Learning Approach}

A view of learning as a social construction where knowledge is negotiated and acquired through social interaction rather than being transmitted by the teacher is central in this pedagogical intervention. This view acknowledges the importance of interaction, peer mediation, and scaffolding (Vygotsky, 1978). Therefore, after a look at some approaches in education, and based on the positive outcomes that some research studies have shown in terms of cognitive, personal, and social development (González, 2001; Parga, 2011; Sánchez, 2011), we consider that cooperative learning is suitable to promote a social construction of knowledge, mutual learning, and at the same time, personal and social development, students' interaction in the classroom, and language development. 
According to Smith and MacGregor (1992), cooperative learning is a form of collaborative learning that involves groups of students working together to develop a specific activity. By working together, students are involved in supportive environments that promote interaction and scaffolding, they get the basis for interacting, practicing different teamwork skills, taking active part in the learning process, and taking responsibility for their learning.

Cooperative learning provides an excellent opportunity to acquire social skills while participants work in groups, improve their oral communication skills, and go beyond the linguistic aspect promoting better relationships and having a better classroom atmosphere, and this process is developed simultaneously. Through interaction and group work students discover ways of being on task, supporting each other, and learning in a meaningful way.

\section{Classroom Interaction at the Heart of Communication}

Language learning as a social process implies interaction as a key element, which requires the presence of two or more learners to achieve communication (Malamah-Thomas, 1991). Brown (1994) stresses that interaction is the heart of communication and the communicative purpose of language should be to create opportunities for genuine interaction in the classroom.

Various researchers (e.g., Castellanos, 2002; González, 2001; Parga, 2011) have investigated the importance of classroom interaction in building knowledge about the language and developing skills that will help learners improve their communicative competence and establish and maintain personal relationships.

Following Freire's (2002) ideas of critical pedagogy and keeping in mind that a real classroom interaction is not a recitation exercise, interaction in this pedagogical intervention is seen as an opportunity for participants, both students and teacher, to express their own ideas or comment on those of others in a dialogical co-construction of knowledge. It is a cyclical process of interaction which means that the initiator of the interaction can be the teacher or the student and that there are no predicted or mechanical responses but a dialogical cycle of action and reflection where students can have an active role that allows for active participation and their voices can be heard.

\section{The Pedagogical Intervention}

This section, which is the core of this methodological paper, aims at presenting a detailed account of the pedagogical implementation, that is, of its construction and development. It first presents the context and participants involved in the intervention; second, it provides a discussion of the visions of curriculum, language, learning, and classroom that served as the pedagogical backup of the implementation; finally, it explains the way the intervention was implemented by 
describing the purpose, the construction and development of the different cycles, the topics, pedagogical objectives and EFL components that got built into the implementation.

\section{Context and Participants}

This pedagogical experience took place at a public school located in the south-east of Bogotá, Colombia. The participants were a group of 30 students from seventh grade, 19 male and 11 female, aged 12 to 15. The school has an English program that places students into three different levels: basic, intermediate, and advanced; according to this classification, the participants were in basic level. These students were chosen because the disrespectful behaviors were more evident in the lower secondary grades, and particularly in this basic EFL class of seventh graders.

\section{Visions Behind the Implementation}

Taking into account that this pedagogical experience aimed to foster students' classroom interaction through cooperative learning principles from a dialogical perspective, one sees it was designed and implemented having in mind a specific curricular platform that included particular visions of curriculum, language, learning, and classroom.

\section{Vision of Curriculum}

As this pedagogical intervention is framed within a critical pedagogy approach, it takes a curriculum perspective that promotes a social construction of knowledge and the development of students' critical consciousness. Grundy (1987) suggests a curriculum as praxis, where teachers promote reflection and action and encourage dialogue with students. This perspective proposes a transformation in education, going against a banking education where, as Freire (2002) states, the teacher attempts to transfer knowledge and the learner is considered a passive empty receiver of that knowledge and, although students face different kinds of social situations in their lives, these situations are not taken into account.

From this transformative perspective, knowledge is a social construction, and the curriculum is a form of social practice occurring in the real world. It is integrated in authentic situations that are meaningful for the participants who have the opportunity to question their reality in order to understand and transform it, and they can develop their own voices to become active agents for social change. According to Grundy (1987) the curriculum is developed through the dynamic interaction of action and reflection, which means that "the curriculum is not simply a set of plans to be implemented, but rather is constituted through an active process in which planning, acting and evaluating are all reciprocally related and integrated into the process" (p. 160). 


\section{Vision of Language}

As teaching a language is a complex process, there is no unique vision of it and, as Tudor (2001) mentions; a full mastery of language involves the mastery of all the elements that language implies. According to Tudor, language is a system, a means of "achieving functional goals, a means of self- expression, and the bearer of a set of cultural values and ideologies" (p. 65). This pedagogical intervention focused on language as self-expression.

This vision of language is embodied in the humanistic perspective. Tudor (2001) points out that language is "a medium by which we build up personal relationships, express our emotions, and explore our interests" (p. 65). The author discusses five main components which have underpinned most humanistic approaches to language teaching: (1) feelings which includes personal emotions and esthetic appreciation; (2) social relations that encourage friendship and cooperation; (3) responsibility that includes and accepts the need of public scrutiny, criticism, and correction; (4) intellect that includes knowledge, reason, and understanding; and (5) self-actualization that looks for full realization of one's qualities.

Through this vision, it is possible to empower students, enabling them to be themselves and at the same time establish interpersonal relations in order to foster cooperative classroom interaction, which is the main goal of this pedagogical experience. The teachers' purpose would be to create the possibility to foster and construct a safe and supportive environment in the classroom where the students could feel confident to express their ideas and respect others without fear or rejection.

\section{Vision of Learning}

The vision of learning embraced in this study is experiential which, according to Tudor (2001), implies that the learning process should foster the use of language as a means of communication. This vision is based on five principles: (1) focus on communication rather than learning about the language; (2) a holistic practice which reflects the multi-dimensional nature of normal communication; (3) the use of authentic material; (4) the use of communication strategies; and (5) the use of collaborative learning where interaction raises the learning processes.

In this pedagogical intervention, the activities were planned in order to enhance interaction and promote effective communication among students. For Tudor (2001), students are seen as "individuals whose interaction with learning activities is influenced by a variety of cognitive, psychological, and experiential factors" (p. 95). It implies that students are not only language learners but, as Tudor mentions, they are complex human beings who interact in an individual manner, creating a personal understanding of language and language learning. Language learning will be effective if it is meaningful for them. Teachers should find 
ways of fitting the learning process in students' needs, interests, and social contexts, so they can freely express their thoughts and opinions.

\section{Vision of Classroom}

The vision of classroom in this curricular platform includes two perspectives: the vision of classroom as a place for communication and the classroom as socialization. These two visions focus on two important aspects, namely interaction and social reality. Taking into account these visions, one sees that the classroom is a place of communication and also a social setting where language is a goal, but at the same time, it is a means of learning. According to Tudor (2001), "communication in the classroom was the preparation for communicative language outside the classroom" (p. 113), which means there should be a link between the communicative activities being developed in classes and participants' real worlds.

Here the classroom is seen as a social and pedagogical entity. Thus, the language classroom reflects a vision of society, its beliefs and values that influence its dynamics. The classroom is a social reality which is influenced by a variety of participants. Through a process of emergent socialization (Tudor, 2001), participants develop their own rules or norms that are not imposed but that have to be negotiated. ${ }^{1}$ In this vision, the students become active agents who question their reality in order to understand it and transform it.

From a critical perspective, a change from banking to a transformative education implies a self and social change, a student-centered classroom that encourages and respects the voices of students and promotes individual growth as an active, cooperative, and social being. Shor (1992) claims that "the learning process is negotiated, requiring leadership by the teacher and mutual teacher-student authority" (p. 16). In this sense, the classrooms must be places to question, examine, and relate reality to academic knowledge, letting students be part of the learning process.

\section{Description of the Cycles: A Critical Dialogical Construction}

This pedagogical intervention was systematized following the principles of action research, an approach which helps teachers to transform their practices by developing phases of planning, action, observation, and reflection. These stages were developed in four different cycles allowing for analysis and reflection on the information gathered and the activities developed in each cycle and, in that way, planning further action for the subsequent cycles.

1 See Cycle 1 of the pedagogical intervention. 
With a critical pedagogy perspective in mind, and as shown in Table 1, the cycles of this implementation were organized around topics and purposes that fostered cooperative learning, group work, and classroom interaction. These topics and purposes were articulated to the EFL contents included in the course syllabus for seventh graders and were connected to the most immediate personal and social surroundings of the students (i.e., me, my class, my school, and my family).

Following Freire's (2002) and Shor's (1992) views of education, this pedagogical intervention focuses on the students' reality and the ways in which pedagogy transforms that reality; and based upon dialogue, transcends to an education of questioning, reflection, and action. In relation to cooperative learning, we found it relevant to this experience since its principles help to fulfill the objectives established by critical pedagogy because as Gillies, (2007); Johnson, Johnson, and Holubec (1994); and Kagan (1992) highlight, it promotes dialogue, increases active student participation in the classroom, and facilitates the development of social skills.

The purpose thus, was to provide opportunities for students to know, understand, and transform their reality and develop social skills while using the foreign language to express themselves. Table 2 shows a summary of the pedagogical intervention, including the cycles, the number of sessions and dates, the topics students developed through group work, the pedagogical objectives, and the EFL component developed in each session which is expressed in terms of communicative functions of language.

Table 1. Pedagogical Intervention: Cycles, Topics, Pedagogical Objectives, and EFL Component

\begin{tabular}{|c|c|c|c|c|}
\hline Cycle & $\begin{array}{c}\text { Session } \\
\text { date }\end{array}$ & Topic & Pedagogical objectives & Related EFL component \\
\hline \multirow{3}{*}{ 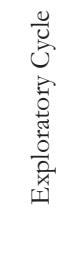 } & $\begin{array}{l}1 \\
\text { Feb. } 25\end{array}$ & \multirow{3}{*}{$\begin{array}{l}\text { Getting to } \\
\text { know each } \\
\text { other }\end{array}$} & \multirow{2}{*}{$\begin{array}{l}\text { - To get to know one another } \\
\text { and enhance empathy } \\
\text { among students. } \\
\text { - To introduce classmates to } \\
\text { the rest of the class. }\end{array}$} & \multirow{2}{*}{$\begin{array}{l}\text { - Asking and giving personal } \\
\text { information about others. } \\
\text { - Introducing other people. }\end{array}$} \\
\hline & $\begin{array}{l}2 \\
\text { March } 4\end{array}$ & & & \\
\hline & $\begin{array}{l}3 \\
\text { March } 11\end{array}$ & & \multicolumn{2}{|l|}{ Initial Questionnaire } \\
\hline
\end{tabular}




\begin{tabular}{|c|c|c|c|c|}
\hline Cycle & $\begin{array}{c}\text { Session } \\
\text { date }\end{array}$ & Topic & Pedagogical objectives & Related EFL component \\
\hline \multirow{5}{*}{$\begin{array}{l}\overrightarrow{0} \\
\text { ơ }\end{array}$} & $\begin{array}{l}4 \\
\text { April } 15\end{array}$ & \multirow{5}{*}{$\begin{array}{l}\text { Me, my team, } \\
\text { and my class }\end{array}$} & $\begin{array}{l}\text { - To build teams. } \\
\text { - To get to know team } \\
\text { members. } \\
\text { - To identify team } \\
\text { commonalities based on } \\
\text { preferences among the } \\
\text { members of the team. }\end{array}$ & $\begin{array}{l}\text { - Asking and giving personal } \\
\text { information about myself and } \\
\text { others. } \\
\text { - Expressing preferences related } \\
\text { to food, sports, TV programs, } \\
\text { leisure activities, clothes, color, } \\
\text { place to be, song, school } \\
\text { subject, movie, and person to } \\
\text { visit. } \\
\text { - Identifying team commonalities. }\end{array}$ \\
\hline & $\begin{array}{l}\mathbf{5} \\
\text { April } 25\end{array}$ & & $\begin{array}{l}\text { - To choose a team name and } \\
\text { select students' roles. } \\
\text { - To identify team qualities } \\
\text { required to work together. } \\
\text { - To design name tags and a } \\
\text { group emblem. }\end{array}$ & $\begin{array}{l}\text { - Talking about possible names } \\
\text { for their group and the roles in } \\
\text { a group (manager, time keeper, } \\
\text { speaker, go for, praiser, etc.). } \\
\text { - Identifying the team qualities. } \\
\text { - Identifying and describing } \\
\text { simple objects (emblem and } \\
\text { name tags). }\end{array}$ \\
\hline & $\begin{array}{l}6 \\
\text { May } 6\end{array}$ & & $\begin{array}{l}\text { To establish agreements to } \\
\text { work and to interact in small } \\
\text { groups. }\end{array}$ & $\begin{array}{l}\text { - Talking about group and class } \\
\text { agreements. } \\
\text { - Making decisions about } \\
\text { agreements that foster group } \\
\text { work and class interaction. }\end{array}$ \\
\hline & & & $\begin{array}{l}\text { To establish agreements to } \\
\text { work and to interact in the } \\
\text { classroom. }\end{array}$ & \\
\hline & & & \multicolumn{2}{|l|}{ Outcome: Poster design. } \\
\hline $\begin{array}{l}\text { N } \\
\frac{0}{0} \\
3\end{array}$ & $\begin{array}{l}8 \\
\text { Aug. } 8\end{array}$ & $\begin{array}{l}\text { Me and my } \\
\text { school } \\
\text { community }\end{array}$ & $\begin{array}{l}\text { - To understand and define } \\
\text { the word "community". } \\
\text { - To get to know the school } \\
\text { community. } \\
\text { - To interview the school } \\
\text { community. }\end{array}$ & $\begin{array}{l}\text { - Understanding and expressing } \\
\text { ideas about community. } \\
\text { - Identifying the school } \\
\text { community. } \\
\text { - Asking and giving information } \\
\text { about the members of the } \\
\text { school community. }\end{array}$ \\
\hline
\end{tabular}




\begin{tabular}{|c|c|c|c|c|}
\hline Cycle & $\begin{array}{c}\text { Session } \\
\text { date }\end{array}$ & Topic & Pedagogical objectives & Related EFL component \\
\hline \multirow{4}{*}{$\begin{array}{l}N \\
0 \\
0 \\
j\end{array}$} & $\begin{array}{l}\mathbf{9} \\
\text { Aug. } 15\end{array}$ & $\begin{array}{l}\text { Me and my } \\
\text { school } \\
\text { community }\end{array}$ & $\begin{array}{l}\text { To reflect upon the school } \\
\text { community: roles and } \\
\text { responsibilities } \\
\text { - To reflect upon the } \\
\text { students' roles, rights, and } \\
\text { responsibilities at school. }\end{array}$ & $\begin{array}{l}\text { - Identifying the school } \\
\text { community: work places, roles, } \\
\text { and responsibilities. } \\
\text { - Talking about the students' role, } \\
\text { rights and responsibilities at } \\
\text { school. }\end{array}$ \\
\hline & $\begin{array}{l}10 \\
\text { Sept. } 2\end{array}$ & \multirow{3}{*}{$\begin{array}{l}\text { Rights and } \\
\text { responsibiliti- } \\
\text { es at School }\end{array}$} & $\begin{array}{l}\text { - To understand and define } \\
\text { rights and responsibilities in } \\
\text { general. } \\
\text { - To reflect on the } \\
\text { importance of rights and } \\
\text { responsibilities in general. }\end{array}$ & $\begin{array}{l}\text { - Understanding and identifying } \\
\text { rights and responsibilities. } \\
\text { - Talking about the importance } \\
\text { of rights and responsibilities. }\end{array}$ \\
\hline & \multirow[t]{2}{*}{$\begin{array}{l}11 \\
\text { Sept. } 19\end{array}$} & & $\begin{array}{l}\text { - To reflect upon students' } \\
\text { rights and responsibilities at } \\
\text { school. } \\
\text { - To analyze the rights and } \\
\text { responsibilities included in } \\
\text { the School Handbook. } \\
\text { - To propose actions to } \\
\text { contribute to the care of the } \\
\text { school. }\end{array}$ & $\begin{array}{l}\text { - Identifying the students' rights } \\
\text { and responsibilities at school. } \\
\text { - Expressing their opinions about } \\
\text { their rights and responsibilities } \\
\text { at school. } \\
\text { - Talking about actions to } \\
\text { contribute to the care of the } \\
\text { school. }\end{array}$ \\
\hline & & & Outcome: Friso & \\
\hline \multirow[t]{2}{*}{$\begin{array}{l}m \\
0 \\
0 \\
0\end{array}$} & $\begin{array}{l}12 \\
\text { Oct. } 17\end{array}$ & \multirow[t]{2}{*}{$\begin{array}{l}\text { Me and my } \\
\text { family }\end{array}$} & $\begin{array}{l}\text { - To reflect on the family as a } \\
\text { community and its } \\
\text { importance in our lives. } \\
\text { - To describe the members of } \\
\text { the family and write a short } \\
\text { paragraph about them. }\end{array}$ & $\begin{array}{l}\text { - Understanding and talking } \\
\text { about family and its importance } \\
\text { in our lives. } \\
\text { - Identifying and giving } \\
\text { information about the members } \\
\text { of the family (name, age, place } \\
\text { of birth, occupation, } \\
\text { personality, favorite activity and } \\
\text { dreams). }\end{array}$ \\
\hline & $\begin{array}{l}13 \\
\text { Oct. } 21\end{array}$ & & $\begin{array}{l}\text { To identify and reflect on } \\
\text { the qualities that a family } \\
\text { should have. } \\
\text { - To propose actions to } \\
\text { promote those qualities in } \\
\text { the family. }\end{array}$ & $\begin{array}{l}\text { - Identifying and expressing their } \\
\text { opinions about the qualities that } \\
\text { the family should have. } \\
\text { - Talking about actions to } \\
\text { promote those qualities in the } \\
\text { family. }\end{array}$ \\
\hline
\end{tabular}




\begin{tabular}{|c|c|c|c|c|}
\hline Cycle & $\begin{array}{l}\text { Session } \\
\text { date }\end{array}$ & Topic & Pedagogical objectives & Related EFL component \\
\hline \multirow{3}{*}{ 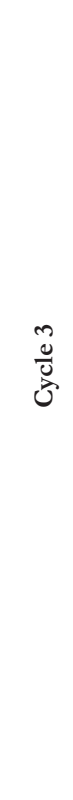 } & $\begin{array}{l}14 \\
\text { Oct. } 28\end{array}$ & $\begin{array}{l}\text { Rights and } \\
\text { responsibiliti- } \\
\text { es in my } \\
\text { family }\end{array}$ & $\begin{array}{l}\text { - To reflect upon the rights } \\
\text { and responsibilities of the } \\
\text { members of the family. } \\
\text { - To reflect on students' own } \\
\text { rights and responsibilities in } \\
\text { relation to the family. } \\
\text { - To propose actions to } \\
\text { contribute to the family as a } \\
\text { community and improve the } \\
\text { family relationships. }\end{array}$ & $\begin{array}{l}\text { - Identifying and describing the } \\
\text { rights and responsibilities of the } \\
\text { members of the family. } \\
\text { - Identifying and describing } \\
\text { students' rights and } \\
\text { responsibilities in the family. } \\
\text { - Talking about actions to } \\
\text { contribute to the family as a } \\
\text { community and improve the } \\
\text { family relationships. }\end{array}$ \\
\hline & $\begin{array}{l}15 \\
\text { Nov. } 14\end{array}$ & $\begin{array}{l}\text { Our } \\
\text { Handbook }\end{array}$ & \multicolumn{2}{|l|}{ Outcome: Handbook Creation } \\
\hline & $\begin{array}{l}16 \\
\text { Nov. } 25\end{array}$ & $\begin{array}{l}\text { Socialization } \\
\text { of the project }\end{array}$ & $\begin{array}{l}\text { - To organize an oral } \\
\text { presentation to share the } \\
\text { outcomes of the } \\
\text { intervention. } \\
\text { - To explain and describe to } \\
\text { the school community the } \\
\text { group work developed } \\
\text { during the pedagogical } \\
\text { intervention. }\end{array}$ & $\begin{array}{l}\text { - Talking about what the students } \\
\text { did during the pedagogical } \\
\text { intervention. } \\
\text { - Expressing their opinions and } \\
\text { feelings about this experience. }\end{array}$ \\
\hline
\end{tabular}

The instructional design was thus composed of four cycles with sixteen sessions developed in sixteen weeks. There was an initial exploratory cycle called "Getting to know each other" developed in three sessions. Here, the students introduced themselves, met their classmates, and shared personal information. During this process, their interactions were systematically observed and, through a questionnaire applied at the end of this initial cycle, we gathered their personal information, information about their family and school contexts, and about their relationships at school and family levels. Based on this preliminary observation and the information gathered through the questionnaire, we could choose the main topics that were to be developed in each subsequent cycle.

The topics in Cycle 1 were me, my team, and my class. In Cycle 2, the main topics were: me and my school community and rights and responsibilities at school; and in Cycle 3, the topics were: me and my family, and rights and responsibilities in my family. These topics were chosen keeping in mind that, according to the critical pedagogy perspective, it is necessary to relate whatever students learn to their world and the realities of their world. These were articulated with pedagogical 
objectives that aimed at fostering group work, cooperative learning and social skills while encouraging students to use the foreign language to share and construct meaning.

The key moments of each cycle. Additionally, each cycle was developed in three main moments that helped us involve students' reality in the learning process and plan activities that engaged students in a permanent dialogical process of reflection that let them know, understand, and propose actions to transform their reality. These moments in which the complete pedagogical experience was framed were: reading the world, learning about the world, and changing the world. In the first moment, reading the world, the students focused on their particular reality and explored and learned more about it. They had the opportunity to activate their previous knowledge about the reality analyzed and link it to the new ideas introduced in each cycle. Then, in the second moment, learning about the world, the students could learn about specific aspects related to each context that let them understand their reality. Finally, in the third moment, changing our world, students reflected on what they had learned in order to propose actions to transform it. Table 2 shows how these moments were developed in each cycle.

Table 2. The Cycles and the Central Moments

\begin{tabular}{||l|l|l||}
\hline \multicolumn{1}{|c|}{ Cycles } & \multicolumn{1}{|c||}{ Moments } & \multicolumn{1}{c|}{ Description } \\
\hline & \multirow{2}{*}{ 1. Reading the world } & $\begin{array}{l}\text { Exploring group work and } \\
\text { recognizing myself and others. }\end{array}$ \\
\cline { 2 - 4 } & \multirow{2}{*}{ 2. Learning about the world } & $\begin{array}{l}\text { Learning about the roles and } \\
\text { responsibilities in a group and } \\
\text { choosing them according to my own } \\
\text { and others' qualities and abilities. }\end{array}$ \\
\cline { 2 - 4 } Me, my team, and my class & 3. Changing our world & $\begin{array}{l}\text { Reflecting on the qualities that the } \\
\text { group should have. } \\
\text { Making decisions and proposing } \\
\text { agreements to work, interact, and } \\
\text { have better relationships with the } \\
\text { team members, based on the group } \\
\text { characteristics. }\end{array}$ \\
\hline $\begin{array}{l}\text { Me and my school community } \\
\text { Rights and responsibilities at school }\end{array}$ & 1. Reading the world & $\begin{array}{l}\text { Exploring the concept of community } \\
\text { and its different types. }\end{array}$ \\
\hline \hline
\end{tabular}




\begin{tabular}{|c|c|c|}
\hline Cycles & Moments & Description \\
\hline \multirow{2}{*}{$\begin{array}{l}2 \\
\text { Me and my school community } \\
\text { Rights and responsibilities at school }\end{array}$} & 2. Learning about the world & $\begin{array}{l}\text { Learning about the school } \\
\text { community, its members, their work } \\
\text { places, and roles. }\end{array}$ \\
\hline & 3. Changing our world & $\begin{array}{l}\text { Reflecting upon students' own and } \\
\text { others' rights and responsibilities at } \\
\text { school. } \\
\text { Proposing actions to contribute to } \\
\text { the care of the school. }\end{array}$ \\
\hline \multirow{3}{*}{$\begin{array}{l}3 \\
\text { Me and my family } \\
\text { Rights and responsibilities in my } \\
\text { family }\end{array}$} & 1. Reading the world & $\begin{array}{l}\text { Talking about the family as a } \\
\text { community and discussing its } \\
\text { importance in our lives. }\end{array}$ \\
\hline & 2. Learning about the world & $\begin{array}{l}\text { Learning more about students' family } \\
\text { members (their responsibilities, their } \\
\text { dreams, and their favorite activities). }\end{array}$ \\
\hline & 3. Changing our world & $\begin{array}{l}\text { Reflecting on the qualities that a } \\
\text { family should have, their roles, rights, } \\
\text { and responsibilities within their } \\
\text { household. } \\
\text { Proposing actions to have a better } \\
\text { relationship with their relatives. }\end{array}$ \\
\hline
\end{tabular}

Cycle 1 was divided into four sessions, the students started the process of working in groups following the principles proposed by different experts in cooperative learning such as Gillies (2007), Johnson et al. (1994), and Kagan (1992). These authors have identified three main types of groups: formal, informal, and base groups. Because of the purpose of this pedagogical intervention, the students were organized in base groups, where students worked for a long period of time and followed a continuous process of work because their members were permanent. In the first moment of this cycle, reading the world, the students reflected on group work, they talked about how they usually work in groups and, the teacher and the students discussed the real meaning of working in groups. Then, the students decided and proposed how to choose the members of their groups and got to know each other as a group. They shared their personal information, talked about their preferences, and identified their common aspects. Then, each group selected a name that represented them as a group.

At the second moment, students learned about the roles and responsibilities that they were going to have within the group. They learned about them through a puzzle where they identified ten roles and their definitions. The roles were: manager, reader, checker, speaker, evaluator, go-for, praiser, timekeeper, artist, and recorder. Then, each member of the group selected the roles that they wanted to perform according to their qualities and abilities. In order to 
identify each group and its members, each student designed a name tag with the name of the group, an emblem, and his/her roles (see Figure 1). Finally, at the third moment, the students were encouraged to reflect on the qualities that their groups should have, make decisions, and propose agreements to work, interact, and have better relationships in their groups and in the classroom (see Figure 2). By means of the activities proposed in this cycle, the students used the foreign language to express their ideas and opinions. Through the foreign language, they asked and gave information to know each other and used the vocabulary related to roles and qualities. As a final product for this cycle the artists of each group got together in order to design a poster with the group and class agreements.

Cycle 2 was divided into four sessions. When reading the world, students shared their ideas and gave examples of communities, and compared their ideas with a definition given by the teacher to propose a new definition. In the second moment, learning about the world, the students had the opportunity to learn about the school community through an interview. Each group selected the person that they were going to interview, and the students designed the questions and the guidelines for the interview. Each group shared the information collected with the rest of the class through a jigsaw activity. ${ }^{2}$ Then, students came back to their original groups and used the information gathered to talk about the school community members and their work places. In the third moment, changing our world, they reflected upon their own and others' rights and responsibilities at school and how they could contribute to the school. They listed some students' rights and responsibilities and then compared them with the ones written in the School Handbook. As a final product of this cycle the students made a friso that included the summary of the reflective work developed in the different

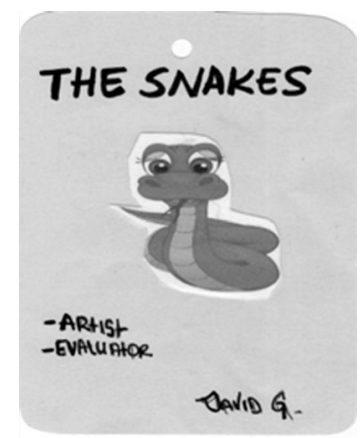

Figure 1. Nametag Sample

2 The jigsaw is a cooperative learning activity in which the members of different groups get together as pieces in a jigsaw to form a new group and share the information that each one has. 


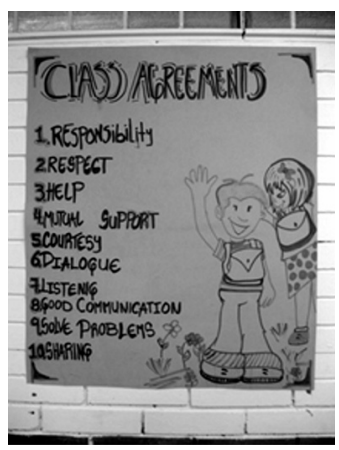

Figure 2. Group Agreements Poster Sample

sessions about their roles, rights, responsibilities in the school, and their actions to contribute to the school community. Each group was encouraged to explain its friso to the whole class using the foreign language (see Figure 3).

Cycle 3 was developed in five sessions. In the first moment, the students and the teacher talked about the family as a community; we then discussed its importance in our lives. In the second moment, the students interviewed their families, made a family tree, and wrote short paragraphs with the information collected. Then, in the third stage, they reflected on the qualities that a family should have, their roles, rights, and responsibilities within their household, and the students proposed actions to have a better relationship with their relatives. The students had the opportunity to use the foreign language to describe and share the information collected about their families, express their ideas about their rights, responsibilities, and planned actions.

The last two sessions closed the pedagogical intervention and let the students gather and share all the work developed during these cycles in two activities. The first activity was the creation of Our Handbook that was the final product of this cycle. Here, the students recorded the agreements and actions they decided to implement in their groups, in the classroom, at school, and in their homes to transform and improve their social relations as well as their contexts. Each group presented the handbook to the whole class and was motivated to use English to do that.

The second activity was the socialization of the pedagogical intervention with the school community. The students showed their work, shared it, and talked about their experience during the pedagogical intervention. A leaflet was designed in order to invite the whole school community to the event, which was held on November 25 in the English classroom. 


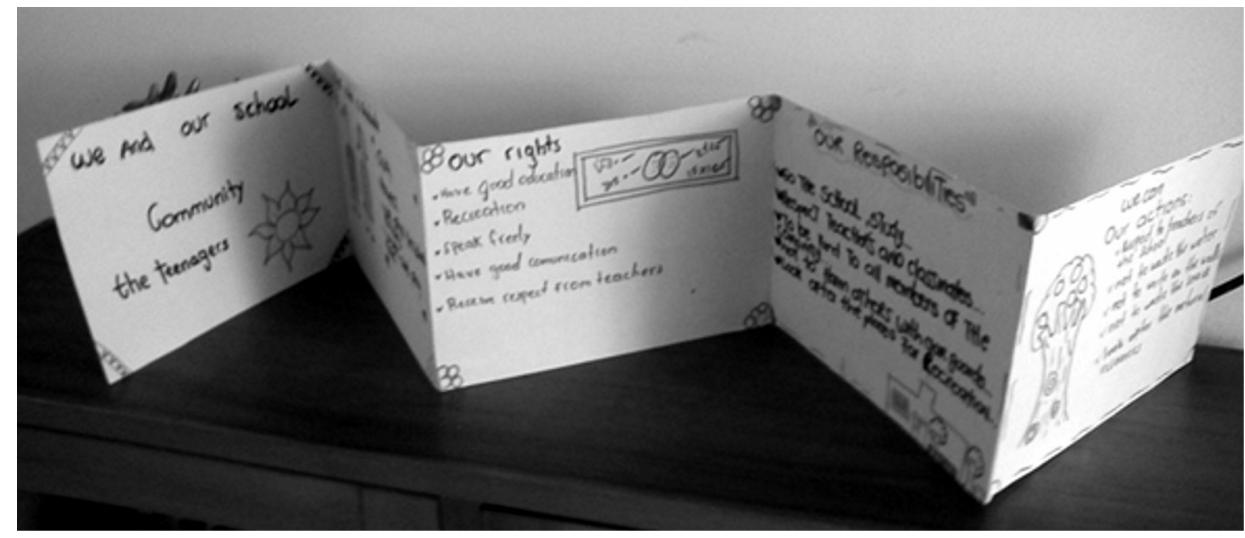

Figure 3. The Teenager Group's Friso

\section{Lesson Plans as Key Articulating Elements}

In order to further articulate the critical pedagogy perspective with the pedagogical purposes and the construction of the cycles, lesson plans were drawn up as key elements in this intervention. Thus, handouts were designed and developed in class sessions (see sample in Appendix) along with lesson plans for each cycle and for the last two sessions, which closed the pedagogical intervention. Lesson plans included a background information section plus four other sections that were developed in each session. There was an introductory time where the teacher gave guidelines to develop the activities and both the teacher and students could make decisions and adjustments. In the second section called group work time, the activities were developed to be worked in groups, so the students got together to develop the activity which included the EFL component. There was also a sharing time, where each group presented its work to the rest of the class. Finally, a group and individual reflection time, where the students were encouraged to reflect upon their individual and group work performance and on the activities developed. These sections were helpful to organize the contents of the cycles and sessions taking into account the three main moments of each cycle, cooperative learning, and classroom interaction from a critical pedagogy perspective.

Table 3 presents a sample of the lesson plans developed in one of the sessions from Cycle 3. This sample of a lesson plan includes the pedagogical activities and the sections explained before. 
Table 3. Lesson Plan Sample

\begin{tabular}{|c|c|c|c|c|}
\hline \multicolumn{5}{|c|}{ Pedagogical Intervention: Lesson Plan } \\
\hline Cycle: 3 & Session: 13 & $\begin{array}{l}\text { Topic: Me and } \\
\text { My Family }\end{array}$ & \multicolumn{2}{|l|}{ Date: Oct. 21} \\
\hline Room: C 109 & Grade: 7 th & $\begin{array}{l}\text { Students' level: } \\
\text { Basic }\end{array}$ & Number of Ss: 30 & Time: 100 min. \\
\hline \multirow[t]{2}{*}{$\begin{array}{l}\text { Background } \\
\text { information }\end{array}$} & \multicolumn{4}{|c|}{$\begin{array}{l}\text { - According to the information collected in the exploratory cycle, most of the } \\
\text { students said that they have a good relationship with the members of their family, } \\
\text { but mentioned that they have conflicts with them and would like to change their } \\
\text { family environment. } \\
\text { - The vocabulary related to the family and the language needed for these sessions } \\
\text { were explained and practiced in the previous class (simple present, family members, } \\
\text { occupations, cardinal numbers, and personality adjectives). }\end{array}$} \\
\hline & \multicolumn{4}{|c|}{ Pedagogical activities } \\
\hline $\begin{array}{l}\text { Introductory } \\
\text { time: }\end{array}$ & \multicolumn{4}{|c|}{$\begin{array}{l}\text { - The teacher reminds about the last activity where the students had the opportunity } \\
\text { to interview one of their family members and share with their classmates some } \\
\text { aspects of what they had found about their family members. } \\
\text { - The teacher encourages students to share their opinions and feelings about these } \\
\text { activities and their discoveries. }\end{array}$} \\
\hline Group work time & \multicolumn{4}{|c|}{$\begin{array}{l}\text { In groups, the students develop the second part of the handout where they write } \\
\text { about the reasons why their families are important for them and give examples to } \\
\text { support. Then, they discover some family qualities in a secret coding exercise, and } \\
\text { propose other possible qualities. Finally, students list five of the most important } \\
\text { qualities for their groups and think about actions to promote them in their own } \\
\text { families. }\end{array}$} \\
\hline Sharing time & \multicolumn{4}{|c|}{$\begin{array}{l}\text { Each group reports its answers to the whole class. Students are encouraged to use } \\
\text { English in this sharing time. But the use of their L1 is allowed as a strategy to share } \\
\text { and construct meaning. }\end{array}$} \\
\hline Reflection time & \multicolumn{4}{|c|}{$\begin{array}{l}\text { - Each group fills in the group reflection form. } \\
\text { - Students write in their journals their reflections about their work and the activity. }\end{array}$} \\
\hline
\end{tabular}

\section{Discussion of the Pedagogical Experience}

The implementation of a critical and dialogical perspective in the EFL classroom generated changes in the teaching and learning practices. As a result of this pedagogical 
experience, there was a gradual process that moved students to a broader sphere of their realities in each cycle. This let them explore and reflect on their worlds and, at the same time, use the foreign language to do so. Figure 4 has been designed to show a visual representation of the intervention. Since each cycle was developed in three moments, these encapsulated the whole process that started with the exploratory cycle. This cycle is represented in the smallest oval, here, and individual recognition of the student as a person and as part of the group of students was encouraged. Then, in Cycle 1, the students fostered group and class work and established a better relationship with their teams and classmates. Cycle 2 moved students to a wider context which was the school. They could go beyond the classroom; they knew the school community and recognized themselves as part of it. Finally, in Cycle 3 students had the opportunity to know their family members better, reflect upon their family relationships, and propose actions to improve those relations, thus going beyond the school context.

This pedagogical intervention aimed at valuing students' voices seeking the development of students' critical consciousness, as well as their communicative skills, in a dialogical interaction among students, and between students and the teacher that could help them transform their attitudes and contexts. A change in attitudes was observed in different moments, especially when students were given opportunities to think about their actions and engage in dialogic interactions. For instance, before the second and third cycles, the teacher and the students talked and reflected upon their work and attitudes and, based on those reflections, the groups decided that some students should move to other groups. This decision helped students to focus on their group work, have better relationships, and reflect upon their individual and group responsibilities.

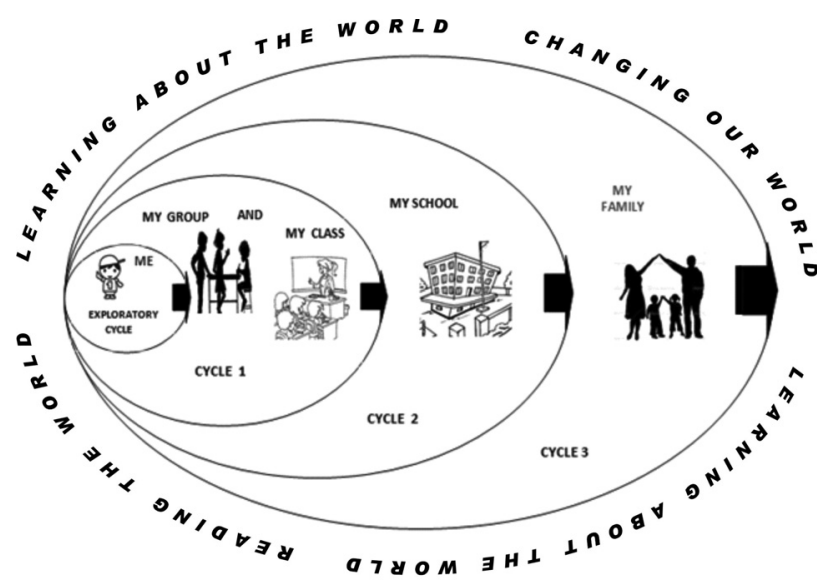

Figure 4. Visual Representation of the Pedagogical Intervention 
The pedagogical experience also showed that developing activities that take students beyond the classroom bounds can be very encouraging. As an example, students were motivated with the design and development of the interviews because it was the first time that they could go out of the classroom to get to know all the school community. Going around the school to interact with the community, wearing their name tags, gave them a sense of belonging and a feeling of responsibility as members of a group who have an active role. For this reason, students and the teacher decided to include interviews as an activity in the next cycle so that they could talk with and listen to family members to gather the information.

This dialogical perspective not only changed the teaching and learning practices allowing a balanced relationship among participants, and a new vision and practice of group work, but also encouraged personal growth, social awareness among students, and helped them communicate in the foreign language. In the different moments and stages of the intervention, students found themselves using language as a social practice and as a means to communicate and name the world.

\section{Conclusions and Implications}

This pedagogical intervention shows that it is possible to foster students' interaction through cooperative learning from a dialogical perspective and go beyond traditional teaching practices common in public schools. Taking into account an approach in which language is viewed as a social practice where teachers encourage social awareness and promote spaces for interaction and critical reflection, it was possible to incorporate and articulate EFL syllabus contents with the students' realities in order to help them understand and reflect upon those realities and become, little by little, active agents who can contribute to the transformation of their social contexts.

The English class could become a learning space that goes beyond grammatical and linguistic features of the language to promote critical and conscious agents that are able to use knowledge to transform their reality. As Chapetón (2007) asserts, the role of an English teacher goes beyond the instructional tasks and, although it is important to take into account the linguistic components, "the critical, living connections with the sociocultural and political arena of the realities we live in our country cannot be overlooked in education" (p. 101).

It is worth highlighting that when we as teachers value the familiar and social context of our students, when we include topics that are familiar to the students, they feel identified and the learning process is more meaningful. This goes in line with Palacios and Chapetón (2014) who found that when EFL class activities "are related to students' real lives, they feel motivated, committed, and willing to take an active part in the class as it becomes enjoyable and meaningful" (p. 27). Besides that, we think that taking into account students' reality also helps teachers to learn more about them and understand students' attitudes. It is important to have in mind that we are working with human beings that come to school to learn but who 
also need affection and care. Thus, by being conscious of the student's reality, we can find ways to help our students to be better students, better citizens, and better human beings.

This pedagogical intervention has had an impact on our teaching practice. It has made us more critical of our practices helping us to gain understanding of the social issues present at the public school context and how these issues may influence the teaching learning process. It also provided important insights to foster student's interaction and social awareness that deserve further exploration.

\section{References}

Areritola, K., Breen, J., \& Paz, E. (2009). Increasing on-task behavior through the development of classroom social skills. Retrieved from ERIC database. (ED505020)

Brown, H. D. (1994). Teaching by principles: An interactive approach to language pedagogy. New York, NY: Longman.

Castellanos, A. (2002). Management of children's aggressiveness when playing competitive games in the English class. PROFILE Issues in Teachers' Professional Development, 3(1), 72-77.

Chapetón, C. M. (2007). Literacy as a resource to build resiliency. Bogotá, CO: Fondo Editorial Universidad Pedagógica Nacional.

Freire, P. (2002). Pedagogy of the oppressed (30th anniversary edition). New York, NY: Continuum.

Freire, P., \& Shor, I. (1987). A pedagogy for liberation: Dialogues on transforming education. Westport, CT: Bergin \& Garvey.

Gillies, R. (2007). Cooperative learning: Integrating theory and practice. Thousand Oaks, CA: Sage. http:/ /dx.doi.org/10.4135/9781483329598.

González, S. H. (2001). Encouraging interaction by applying cooperative learning. PROFILE Issues in Teacher's Professional Development, 2(1), 28-30.

Grundy, S. (1987). Curriculum: Product or praxis? London, UK: Falmer Press.

Guzmán, E. (2006, March 18). Indiferencia hacia la Bogotá joven: la situación en Usme, Ciudad Bolívar y San Cristóbal [The indifference towards Bogotá's youth: The situation at Usme, Ciudad Bolivar and San Cristobal]. Desde Abajo, 110.

Johnson, D. W., Johnson, R. T., \& Holubec, E. (1994). The new circles of learning: Cooperation in the classroom and school. Alexandria, VA: The Association for Supervision and Curriculum Development.

Kagan, S. (1992). Cooperative learning. San Clemente, CA: Kagan Publishing.

Malamah-Thomas, A. (1991). Classroom interaction. Oxford, UK: Oxford University Press.

Palacios, N., \& Chapetón. C. M. (2014). Students' responses to the use of songs in the EFL classroom at a public school in Bogotá: A critical approach. GIST Education and Learning Research Journal, 9(July-December), 9-30.

Parga, F. (2011). Cooperative structures of interaction in a public school EFL classroom in Bogotá. Colombian Applied Linguistics Journal, 13(1), 24-38. 
Rojas, L. F. (2015). Factors affecting academic resilience in middle school students: A case study. GIST Education and Learning Research Journal, 11(July-December), 63-78.

Sánchez, Y. (2011). Applying cooperative learning in large groups (Unpublished undergraduate monograph). Institución Universitaria Colombo Americana (UNICA), Bogotá, Colombia.

Shor, I. (1992). Empowering education: Critical teaching for social change. Chicago, IL: University of Chicago Press.

Smith, B. L., \& MacGregor, J. T. (1992). What is collaborative learning? Retrieved from https://umdrive.memphis.edu/ggholson/public/collab.pdf.

Tarone, E. (2007). Sociolinguistic approaches to second language acquisition research. The Modern Language Journal, 91, 837-848. http://dx.doi.org/10.1111/j.1540-4781.2007.00672.x.

Tudor, I. (2001). Visions of learning in the dynamics of the language classroom. Cambridge, UK: Cambridge University Press.

Vygotsky, L. S. (1978). Mind in society: The development of higher psychological processes. Cambridge, MA: Harvard University Press.

\section{The Authors}

Janeth Juliana Contreras León holds a BA in Modern Languages (Spanish and English) from Universidad Distrital Francisco José de Caldas, Colombia, and an MA in Foreign Language Teaching from Universidad Pedagógica Nacional de Colombia. She is an EFL teacher for the Secretary of Education in Bogota at Colegio Bravo Páez IED.

Claudia Marcela Chapetón Castro holds a PhD in Applied Linguistics (University of Barcelona) and an MA in Applied Linguistics (Universidad Distrital Francisco José de Caldas). She is an associate professor at Universidad Pedagógica Nacional, Bogotá. She has co-authored EFL textbooks and teaching materials. Her research interests include critical literacy practices, EFL teaching, metaphor, and corpus linguistics. 


\section{Appendix: Handout Sample}

Public School Name:

Learning About the World - Cycle 2

Rights and Responsibilities

Name: Grade: 70 Date:

1. Draw lines to match the pictures with the expressions.
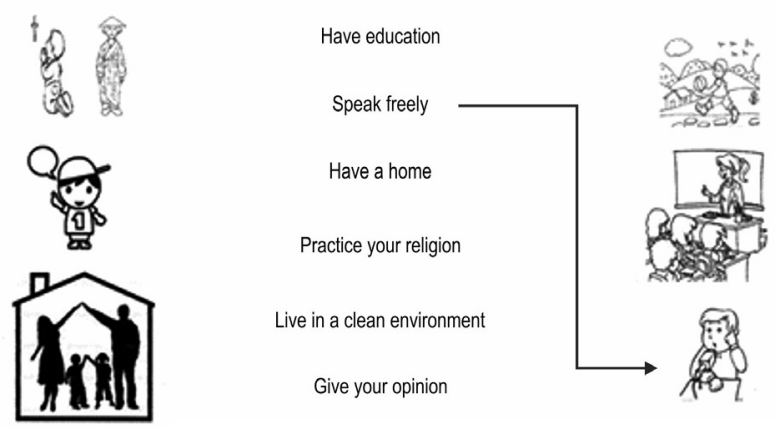

2. Match the rights in the first column with the responsibilities in the second column.

Write the letter from each RESPONSIBILITY next to the number of the corresponding RIGHT.

\section{RIGHT TO...}

1. Live in a clean environment

D 2. Speak freely

3. Practice your religion

4. Have education

5. Have a home

6. Give your opinion

\section{RESPONSIBILITY}
A. To respect other's religions
B. To be kind to all members of the family
C. To respect others' opinions
D. Not to harm others with your words
E. To look after the natural resources
F. To learn as much as your capabilities will allow

3. Discuss with your group:

- Do you have rights at school?

Yes $\mathrm{No} \mathrm{O}$ 
- Why?

- Do you have responsibilities at school?

Yes $\mathrm{N} \quad$ No O

- Why?

- Fill the chart. List 5 rights that students have at school and the responsibilities that go with them.

\begin{tabular}{||l|l||}
\hline \multicolumn{1}{|c|}{ Right } & \multicolumn{1}{|c||}{ Responsibility } \\
\hline 0. Have good teachers & Respect them \\
\hline 1. & \\
\hline 2. & \\
\hline 3. & \\
\hline 4. & \\
\hline 5. & \\
\hline
\end{tabular}

- Read in your school handbook the students' rights and responsibilities and compare them with the ones that you wrote in the chart. Are they similar? Are they different? Represent them in these Venn diagrams.
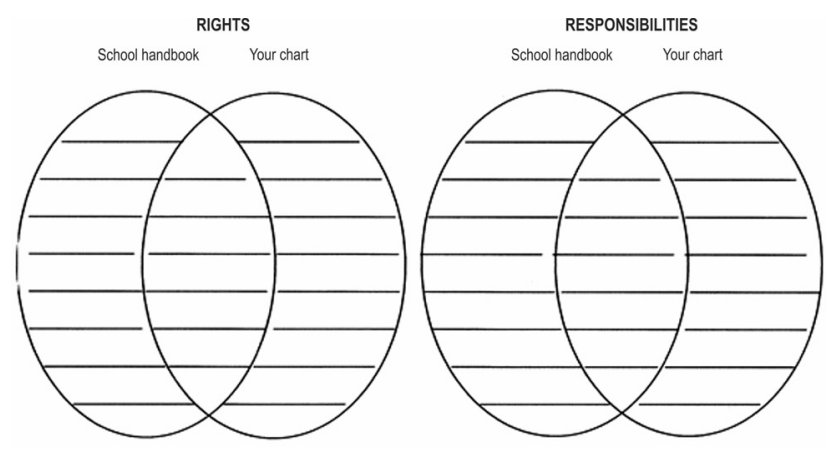